\title{
Late Eocene shoreline volcanism along the continental margin: the volcanic succession at Kabuki Iwa, Oga Peninsula, NE Japan
}

\author{
Takeshi Ohguchi ${ }^{1,2,3}$, Hiromitsu Yamagishi ${ }^{4}$, Norihiko Kobayashi ${ }^{5}$ and Kazuhiko Kano ${ }^{3}$ \\ Takeshi Ohguchi, Hiromitsu Yamagishi, Norihiko Kobayashi and Kazuhiko Kano (2008) Late Eocene \\ shoreline volcanism along the continental margin: the volcanic succession at Kabuki Iwa, Oga Peninsula, \\ NE Japan. Bull. Geol. Surv. Japan, vol.59 (5/6), 255-266, 6 figs, 3 plates.
}

\begin{abstract}
Abstact: Kabuki Iwa (Rock) at the northwestern shore of Oga Peninsula is composed of Late Eocene basaltic andesite aa lava flows and pillowed lava flows, dacitic pyroclastic flows, debris flows and other epiclastic rocks. This close association of the subaerial and subaqueous volcanic products demonstrates a transitional environment between land and shallow water. NE-SW-trending parallel dikes and normal faults are also associated with these rocks in the surrounding areas, and the volcanic succession at Kabuki Iwa is interpreted to have accumulated in an extensional basin which slowly subsided with volcanism before the rapid opening of the Japan Sea.
\end{abstract}

Keywords: Late Eocene, shoreline volcanism, continental margin, volcanic succession, Kabuki Iwa, Oga Peninsula, NE Japan

\section{Introduction}

The Oga Peninsula is situated on the Japan Sea side of the NE Japan Arc (Fig. 1). A Cenozoic succession is well exposed along the coast and has been referred to as a type of Cenozoic succession of northern Japan since Huzioka (1959) established the stratigraphic framework of the succession. Volcanic rocks are extensively exposed in the western part of the peninsula and occupy the lower part of the Cenozoic succession (Huzioka, 1959, 1973). They are believed to represent the initial process of the Japan Sea opening that prevailed during the Early Miocene time, but their volcanological and tectonic aspects remain poorly understood (e.g. Kano et al., 2007a,b, 2008; Kobayashi et al., 2008). This paper describes the occurrence of the volcanic rocks which are exposed at Kabuki Iwa (Rock) near the northern tip of the peninsula (Fig.1), in order to reveal volcanic and associated tectonic activities at that time.

The lower volcanic succession in the western Oga Peninsula is divided into the Akashima Formation, Monzen Formation, and Nomuragawa Formation in ascending stratigraphic order and is unconformably overlain by the Middle to Late Miocene marine sediments of the Nishikurosawa and Onnagawa Formations (Figs. 1 and 2).

The Nomuragawa Formation is a stratigraphic unit newly identified by Kobayashi et al. (2004). This formation comprises mainly dacite pyroclastic flows, basaltic andesite lava flows and scoriaceous deposits and is correlative with the main part of the Daijima Formation distributed on the immediate eastern side (Fig. 2). The Daijima Formation is accompanied by non-marine clastic sediments at its uppermost part, but radiometric dates indicate both the Nomuragawa and Daijima Formations are Early Miocene in age and mutually correlative (Kobayashi et al., 2004).

The Monzen Formation is a mafic to felsic volcanic complex emplaced in a transition area from land to shallow water (Kobayashi et al., 2008) and can be divided into eight units (Fig. 2). Radiometric ages reported for this volcanic succession have been diverse but could span a few million years of Late Eocene to Early Oligocene time (Kano et al., 2007b, 2008). There are many contemporaneous dikes extending mostly in a NE-SW direction, as shown by the geological maps (Huzioka, 1959, 1973), perhaps reflecting an NW-SE extensional stress field of that time (Yamamoto, 1991). The upper most subaqueous rhyolite lava dome of Shinzan Rhyolite is over hundreds of meters thick and suggests the increase of crustal rifting. On the other hand, the overlying Nomuragawa Formation and Daijima Formation are characterized by bimodal volcanism and on-land eruptions. Shallow-water sediments of the uppermost Daijima Formation are likely to record the succeeding subsidence of this area in association with

\footnotetext{
${ }^{1}$ Akita University, 1-1 Tegata Gakuen-machi, Akita, 010-8502

${ }^{2}$ Akita Prefectural Resources Technology Development Organization, 9-3 Furudate, Kosakakozan, Kosaka, Akita 017-0202, Japan

${ }^{3}$ AIST, GSJ, Institute of Geology and Geoinformation, 1-1 Higashi 1-chome, Tsukuba, Ibaraki 305-8567, Japan

${ }^{4}$ Niigata University, Institute of Science and Technology, 8050 Ikarashi 2-no-cho, Nishi-ku, Niigata 950-2181, Japan

${ }^{5}$ INPEX Corporation, Eurasian, Middle East and Africa Business Division, Ebisu 4-1-18, Shibuya-ku, Tokyo 150-0013, Japan
} 


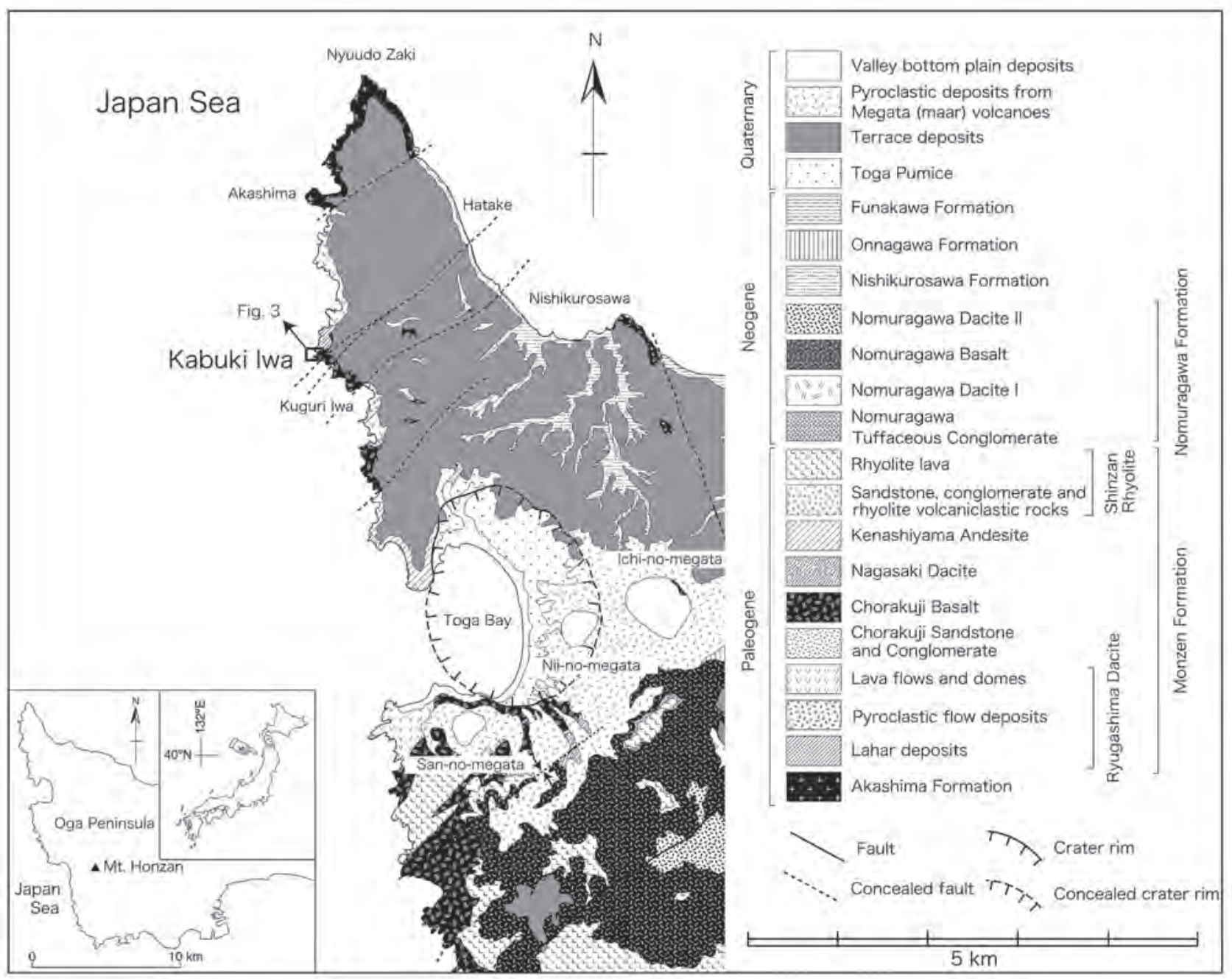

Fig. 1 Geologic map of the western Oga Peninsula, NE Japan, modified after Kobayashi et al. (2008)

the rapid opening of the Japan Sea (Kano et al., 2007a).

\section{Kabuki-Iwa volcanic succession}

Kabuki Iwa constitutes part of the Chorakuji Basalt in the lower Monzen Formation (Kobayashi et al., 2008), which lies mainly horizontally but cut by NESW-trending normal faults (Ohguchi et al., 1987). The Chorakuji Basalt is dominated by basaltic aa lava flows but is locally inter-bedded with non-marine conglomerate, sandstone and finer clastic sediments that contain coaly materials and pollen fossils (Kano et al., 2008). The exposed rocks at Kabuki Iwa are mainly volcanic in origin and are divided into five units I to V (Fig. 3) as described below.

The Monzen Formation ranges mainly from $30 \mathrm{Ma}$ to $35 \mathrm{Ma}$, and a sample from Kabuki Iwa is $34.5 \pm 0.9$ Ma in whole-rock K-Ar age (Ohguchi et al., 1995). ArAr dates of the biotite phenocrysts from the discordantly overlying Shinzan Rhyolites of the same Formation are, however, c. 34 Ma (Kano et al., 2007b). Kabuki Iwa is, therefore, most likely to be Late Eocene in geologic age.

\subsection{Unit I: Lower epiclastic rocks and pumice lapilli tuff}

This unit is exposed on the northern side of Kabuki-Iwa and is composed mainly of epiclastic conglomerate and sandstone of debris flow origin. An inversely or inversely-to-normally graded, matrix-supported conglomerate constitutes the main part of the debris flow deposits and grades upward into stratified sandstone. The conglomerate contains fragments of trachytic andesite 5 to $50 \mathrm{~cm}$ across, and the matrix is composed of sand-sized fragments of similar rocks.

Debris flow deposits of unit I are stacked thick and commonly channel the underlying debris flow deposits with a width of meters and a thickness up to $5 \mathrm{~m}$. The channels extend mainly in a NS direction and cross bedding is locally developed in the channel fills to indicate a current from north to south.

A 1-m-thick bed of biotite-hornblende pumice lapilli tuff occurs at the topmost part of the epiclastic succession. Constituent pumice clasts are up to $10 \mathrm{~cm}$ long, 
Late Eocene shoreline volcanism at Kabuki Iwa, Oga Peninsula (Ohguchi et al.)

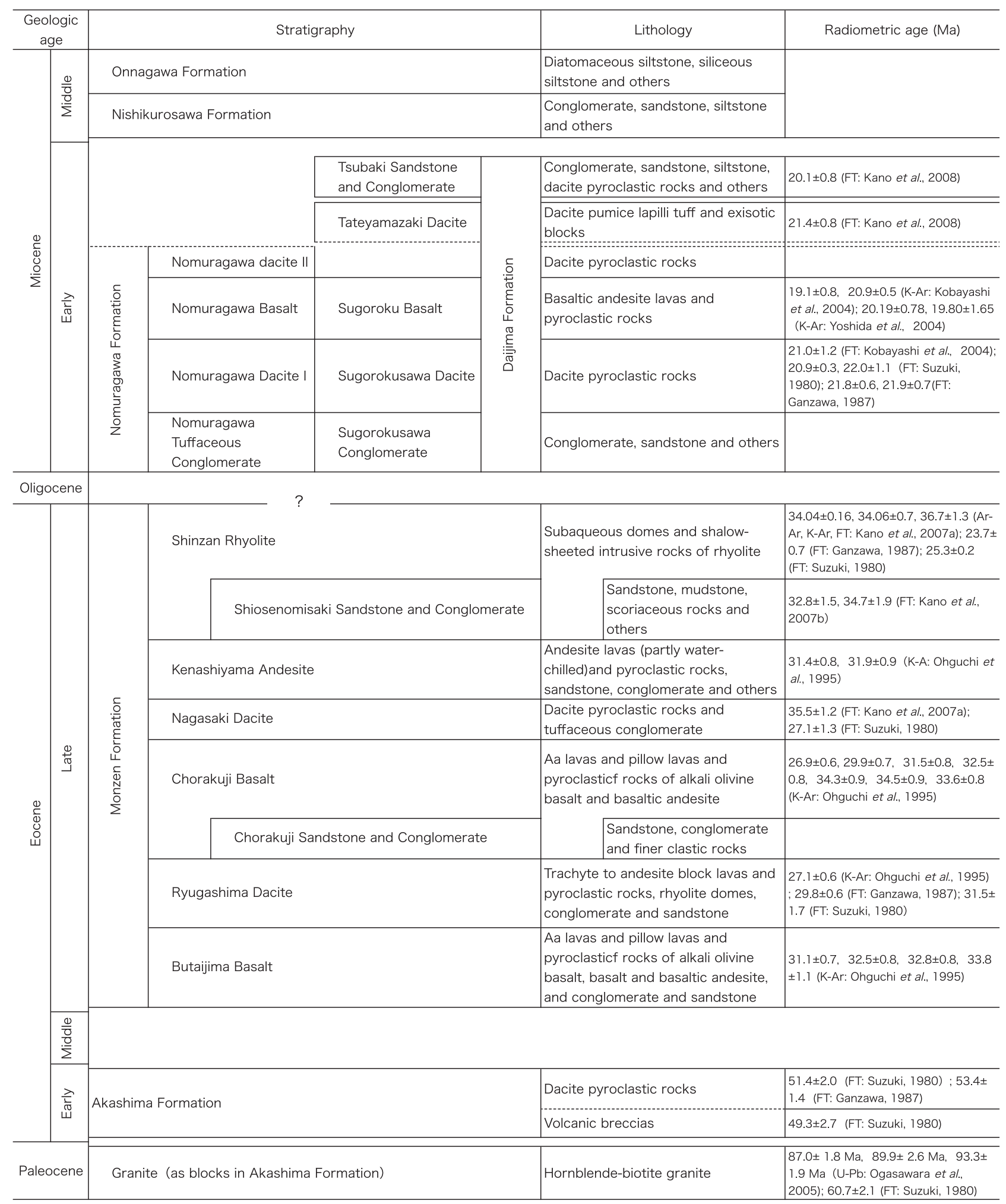

FT: Fission track age, K-Ar: K-Ar age, U-Pb: U-Pb age

Fig. 2 Stratigraphy of the western Oga Peninsula, modified after Kobayashi et al. (2008)

set in a matrix of glass shards and other ash grains and are mutually arranged parallel.

The succession of epiclastic debris flow deposits is interpreted to form a volcaniclastic apron. Pumice lapilli tuff contains no evidence for emplacement at high temperatures but comprises mostly monomictic volcaniclastic materials, and therefore, could be a deposit of pumice flow down on the apron. 


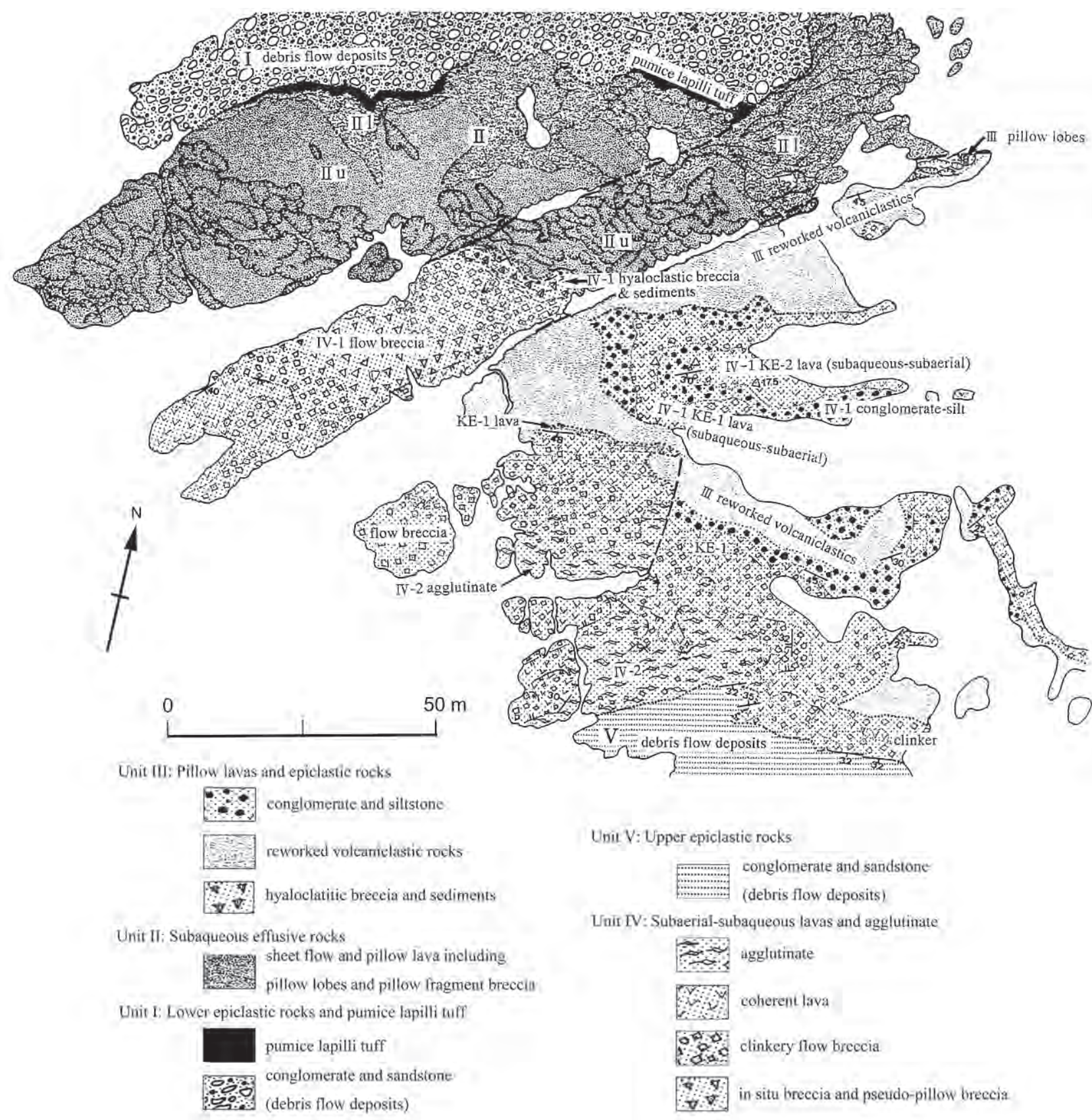

Fig. 3 Geologic map of Kabuki Iwa, Oga Peninsula, NE Japan.

\subsection{Unit II: Subaqueous effusive rocks}

This unit overlies the dacite pumice-lapilli tuff of unit I and contains a variety of volcanic clasts mainly of olivine basaltic andesite. It is divided into the lower unit II-l and upper unit II-u, which are further divided into units II-l-1 (sheet flows), II-l-2 (lava lobes) and II-l-3 (in-situ breccias/flow breccias), and units II-u-1 (pillow lobe) and II-u-2 (pillow fragment breccia) according to their modes of occurrence (Fig. 4).

\subsubsection{Unit II-l: Sheet flows, lava lobes, and flow brec- cias}

The sheet flows of unit II-l-1 have given a stress load to the underlying pumice-lapilli bed. They are jointed at the basal in a $50 \mathrm{~cm}$ interval to form tiny columns $10 \mathrm{~cm}$ long and $15 \mathrm{~cm}$ wide with a glassy margin and are intensely fragmented in situ at the base to form breccias (unit II-1-3). Large fragments of the flow breccias have coarse prismatic joints $1 \mathrm{~m}$ wide. Upper surfaces of the sheet flows are also fragmented in situ. The sheet flows are separated by breccias to make flow units 4 to $8 \mathrm{~m}$ thick. Lava lobes elliptical in plan view and several to ten meters across are extruded from the sheet flows northeastward (unit II-1-2), just like 'toes' of pahoephoe lava flows (Yamagishi, 1991). 


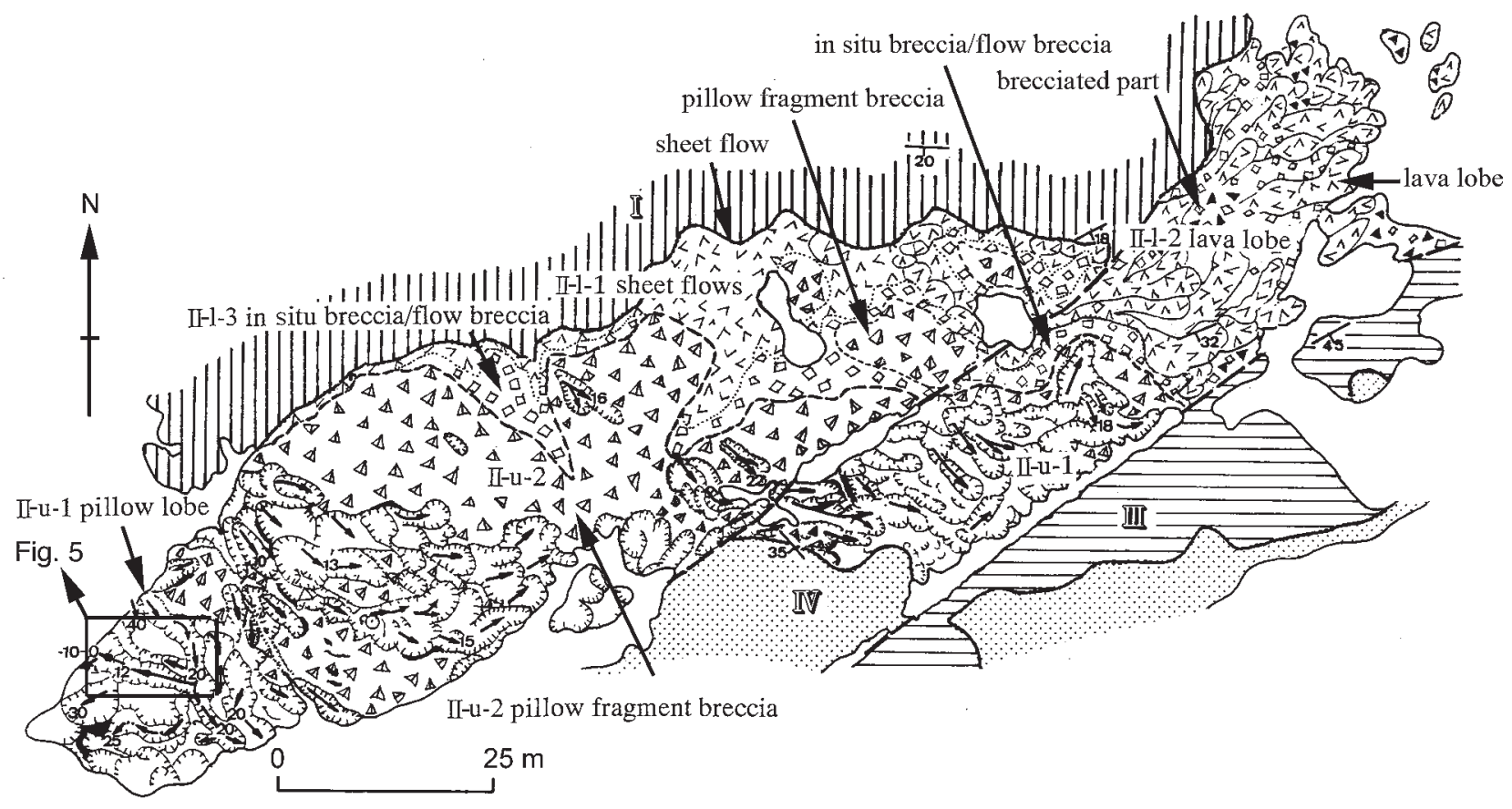

Fig. 4 Sketch map of unit II at Kabuki Iwa.

\subsubsection{Unit II-u: Pillow lobes and pillow fragment breccias}

\section{Unit II-u-1: Pillow lobes}

Pillow lobes in unit II-u-1 well preserve the primary structures (Plates la and 1b; Plates 2a and 2b).

The upper surfaces of pillow lobes are characterized by transverse and longitudinal spreading cracks (Moore, 1975; Yamagishi, 1985), ropy wrinkles, squeezed-up structure and pillow buds (Fig. 5). Transverse spreading cracks show V-shaped depressions, and longitudinal spreading cracks display both V-shaped depressions and tiny grabens. Ropy wrinkles occur on the marginal toes of pillow lobes. They are curved toward the front (Plate 2a and Fig. 4) with a width of 10-20 cm and a length of $1 \mathrm{~m}$ or more and appear to fall down from the source in the longitudinal cross section. An oxidized rigid crust 1-2 cm across shapes the wrinkles. The ridges are blunt or vague, perhaps due to erosion.

Pillow lobes drape down as a cylindrical tube (Plate 1a) or tabular flow (Plate 1b) in diverse directions over a distance of $30 \mathrm{~m}$ (Photogravure 1a of Ohguchi et al., 1987; Plate 1b). Cylindrical tubes dominate on steep slopes and tabular flows appear to dominate on gentle slopes. Walker (1992) defined the former and the latter as flow-foot pillows and tabular pillowed flows, respectively.

Some pillow lobes drape down on considerably steep slopes to commingle their crusts into the interiors or slip down from vertical spreading cracks on the marginal fronts (Yamagishi, 1985). Some other pillow lobes are folded, probably by further lava drains, and left a draping tongue (Photogravure 1c of Ohguchi et al.,

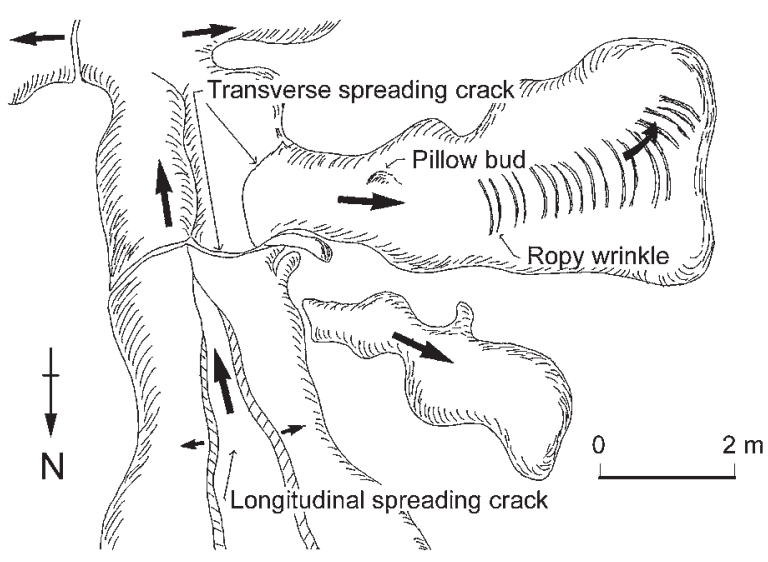

Fig. 5 Schematic sketch of pillow lobes in unit II. The location is shown in Fig. 4.

1987). The other pillow lobes have hollows from which a new pillow lobe draped down (Plate 2b). The interstices between the crusts of the early pillow lobe and the new pillow lobe or between the lava crusts are filled with sandstone to siltstone to form peperite by fluidization of wet sediments (Kokelaar, 1982). These pillow lobes have ellipsoidal vesicles up to a few centimeters across in the interior. They extend mainly from the northwest, diverge to the southeast and continue further to the east or northeast (Fig. 4).

\section{II-u-2: Pillow fragment breccias}

Pillow fragment breccias (Staudigel and Schmincke, 1984) occur along the marginal front of the pillow lobe sequence of unit II-l. They are composed of amoeboid-shaped, isolated pillows with oxidized crusts 
and a matrix of glassy fragments. Calcite and zeolite fill the interstices between the glassy fragments. Collapsing of pillow lobe toes probably formed this unit.

\subsection{Unit III: Pillow lavas and epiclastic rocks}

Pillow lavas of porphyritic olivine-pyroxene basaltic andesite occur at the basal part of unit III and also occur in another southern segment. Constituent pillow lobes are vesicular and are $1 \mathrm{~m}$ across at most. They have, in places, ropy wrinkles $1 \mathrm{~cm}$ wide and high, and also have vertical and longitudinal cracks both of which are $10 \mathrm{~cm}$ wide and up to $15 \mathrm{~cm}$ deep. Some pillow lobes bury the caves of ancient benches and fill the cracks of ancient cliffs of underlying pillow fragment breccias. Pillow lobes decrease in thickness toward the southwest and are interpreted to have flowed from the northeast.

The main part of unit III is occupied by volcanic breccias. The breccias are chaotic and unsorted, composed of angular to sub-rounded fragments of basaltic andesite bombs and blocks, and a heterolithic coarse-grained matrix. They are interpreted as debris flows in origin though inverse grading has not been recognized.

\subsection{Unit IV: Subaerial-subaqueous lavas and agglu- tinate}

Two sheet lavas KE-1 and KE-2 of basaltic andesite are recognized in unit IV. They are up to $5 \mathrm{~m}$ thick and have platy joints, inside of which are rude compared with outer margins. Numerous elongate vesicles up to $2 \mathrm{~cm}$ by $5 \mathrm{~cm}$ long within the lava flows are present along the marginal toes with a preferred-orientation in coincidence with ramp structures (Plate 2c). Aggregates of variably vesicular, partly welded, reddish brown fragments underlie and overlie the sheet lavas with a transitional boundary (Plate 2d). They are over
$50 \mathrm{~cm}$ thick and are replaced by in-situ pseudo-pillow breccias in the southwestern extensions. The vesicular aggregates are interpreted as aa clinkers that constitute part of aa lava flows, and the lateral change into pseudopillow breccias likely represents a subaerial-subaqueous transition (Jones and Nelson, 1970).

Agglutinates occur south of the subaerial to subaqueous lava flows. Amoeboid-shaped (Plate 3a) and spindle-shaped less reddish bombs are $10-30 \mathrm{~cm}$ across (Plate $3 \mathrm{~b}$ ), and their fragments are scattered in the agglutinate. An irregular-shaped dike of a few meters across extends in a direction of $\mathrm{N} 30^{\circ} \mathrm{E}$, and agglutinates accumulate on and along this dike (Plate 3c), presumably to form a spatter rampart produced by lava fountains (Macdonald, 1972). Fragments of bombs, several tens of centimeters across with elongate aa-type vesicles of millimeters to centimeters size, are scattered in chaotic collapse breccias of agglutinate $50 \mathrm{~m}$ away from this interpretative rampart.

\subsection{Unit V: Upper epiclastic rocks}

Stratified volcanic conglomerate beds discordantly overlie unit IV. They are $30 \mathrm{~m}$ thick in total and are composed of cobbles and boulders of andesite and dacite. The conglomerate beds are inter-bedded with sandstone beds of a few tens of centimeters thick and fill channels 5 to $10 \mathrm{~m}$ across. A vertical trace of the boulders and cobbles shows inverse and normal to inverse grading. We suggest that these channel-filling, inversely graded beds are deposits from debris flows and constitute a volcanic apron.

\section{Discussion and summary}

As summarized in Fig. 6, we have recognized the following five units in the Kabuki-Iwa area: unit I (lower

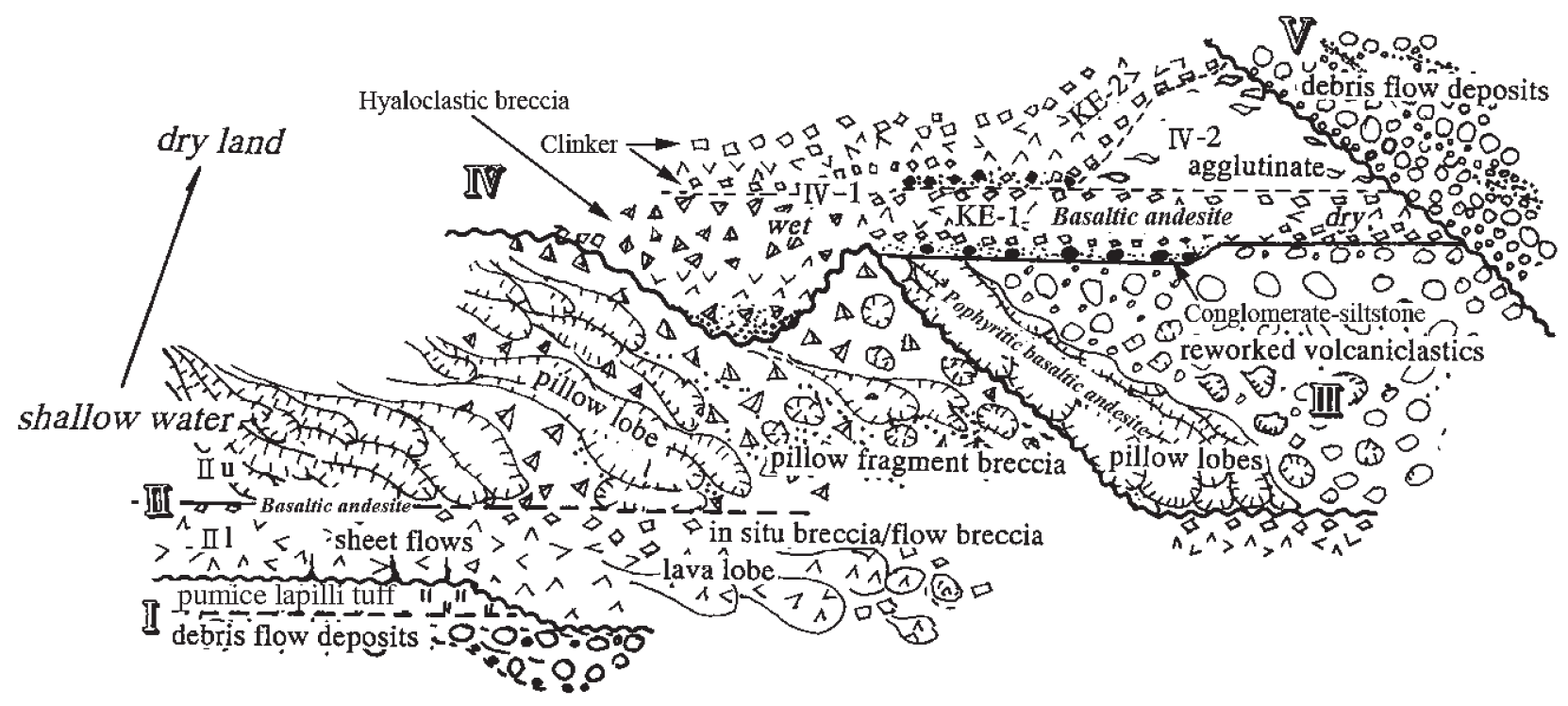

Fig. 6 Schematic illustration of the Kabuki Iwa volcanic succession (not to scale). 
epiclastic volcanic rocks and pumice lapilli tuff), unit II (subaqueous effusive rocks), unit III (pillow lava and epiclastic rocks), unit IV (subaerial-subaqueous lavas and agglutinates), and unit V (upper epiclastic rocks). Pillow lavas are associated with pillow fragment breccias in unit II and are interpreted to have flowed from the northwest to the southeast then further to the northeast. The sheet flows of the overlying unit III are also likely to have flowed toward the south. On the other hand, aa lavas in unit IV flowed toward the southwest, entered water to transform its sheet form over the subaqueous slope and fragmented further into pseudo-pillow breccias. At the same time, Hawaiian/Strombolian eruptions through a fissure vent projected spatter clasts, scoriae, and bombs onto land to produce a spatter rampart.

The Kabuki-Iwa succession records deposition of debris flows and a pumice flow on a volcanic apron of unit I, followed by the eruption of units II, III and IV mentioned above, and the deposition of debris flows of unit V. The host Monzen Formation contains contemporary parallel dike swarms, which extend northeast and indicate an extensional stress field, and the gross accumulation rate of the formation is on an order of 100 m per million years (Kobayashi et al., 2008). In conclusion, the Kabuki-Iwa succession represents volcanic activity at a subaerial-subaqueous transition (Fig. 6) and suggests the presence of a Late Eocene shallow-water area that was slowly subsided on the volcanic front or back-arc side of the volcanic arc at that time.

Acknowledgements: T. Ohguchi and K. Kano were financially supported from the mapping project of the Geological Survey of Japan.

\section{References}

Ganzawa, Y. (1987) Fission track ages of volcanic rocks from Cretaceous to Tertiary in the inner belt of Noetheast Japan - Okushiri Island, Oga Peninsula and Asahi Mountains -. J. Geol. Soc. Japan, 93, 387-401 (in Japanese with English abstract).

Huzioka, K. (1959) 1:50,000 Geological Map of Japan, Toga and Funakawa. 2 sheets with explanatory text, 67 p., Geological Survey of Japan (in Japanese).

Huzioka, K. (1973) Geology of the Oga peninsula, Akita Prefecture, Japan. Research Report Nature Conservation Society of Japan, no. 44, 5-34 (in Japanese).

Jones, J. G. and Nelson, P. H. (1970) The flow of basalt lava from air into water-its structural expression and stratigraphic significance. Geol. Mag., 107, 13-19.

Kano, K., Obuse, A., Sato, Y., Ohguchi, T. and Ogasawara, K. (2008) Chronostratigraphic correlation of the Shiose-no-misaki Sandstone and Conglomerate, Oga Peninsula, NE Japan. J. Japan. Assoc. Petrol. Technol., 73, 88-96 (in Japanese with English abstract).

Kano, K., Sato, Y., Kobayashi, N., Ogasawara, K. and Ohguchi, T. (2007b) Isotopic ages of the Shinzan Rhyolites, Oga Peninsula, NE Japan. J. Japan. Assoc. Petrol. Technol., 72, 608-616 (in Japanese with English abstract).

Kano, K., Uto, K., Ohguchi, T. (2007a) Stratigraphic review of Eocene to Oligocene successions along the eastern Japan Sea: implication for early opening of the Japan Sea. J. Asian Earth Sci., 30, 20-32.

Kobayashi, N., Kano, K. and Ohguchi, T. (2004) The Nomuragawa Formation: proposal for a new stratigraphic unit in the west Oga Peninsula, NE Japan. J. Japan. Assoc. Petrol. Technol., 69, 374-384 (in Japanese with English abstract).

Kobayashi, N., Ohguchi, T. and Kano, K. (2008) Stratigraphic revision of the Monzen Formation, Oga Peninsula, NE Japan. Bull. Geol. Surv, Japan, 59, 211-224 (in Japanese with English abstract).

Kokelaar, B. P. (1982) Fluidization of wet sediments during the emplacement and cooling of various igneous bodies. J. Geol. Soc. London, 139, 21-33.

Macdonald, G. A. (1972) Volcanoes. Prentice-Hall, 510p.

Moore, J. G. (1975) Mechanism of formation of pillow lava. American Scientists, 63, 269-277.

Ogasawara, M., Shimoda, G. and Morishita, Y. (2005) Zircon $\mathrm{U}-\mathrm{Pb}$ age of granite in the Oga Peninsula, Japan. Abstract, 2005 Meeting of Japan. Assoc. Mineral. Petrol. Economic Geol., 27-27 (in Japanese).

Ohguchi, T., Hayashi, S. and Kobayashi, N. (1987) Volcanic facies of the Tertiary volcanic sequences and Quaternary Kampu Volcano in the Oga Peninsula, northeast Inner Japan. Bull. Volcanol. Soc. Japan, 32. 391-393 (in Japanese).

Ohguchi, T., Hayashi, S., Kobayashi, N., Itaya, T. and Yoshida, T. (1995) K-Ar dating unravels the volcanic history of the Kuguriiwa Lava and Kamo Lava Members, Oligocene Monzen Formation, Oga Peninsula, NE Japan. Mem.Geol Soc. Japan, no. 44. 39-54 (in Japanese with English abstract).

Staudigel, H. and Schmincke, H.-U. (1984) The Pliocene seamount series of La Palma/Canary Islands. J. Geophys. Res., 89, 11,915-11,215.

Suzuki, T. (1980) Fission track ages of the Tertiary volcanic rocks in the Oga Peninsula, northern Japan. J. Geol. Soc. Japan, 86, 441-453 (in Japanese with English abstract).

Walker, G. P. L. (1992) Morphometric study of pillowsize spectrum among pillow lavas. Bull. Volcanol., 54, 459-474.

Yamagishi, H. (1985) Growth of pillow lobes-evi- 
dence from pillow lavas of Hokkaido, Japan, and North Island, New Zealand. Geology, 13, 499-502.

Yamagishi, H. (1991) Morphological and sedimentological characteristics of the Neogene submarine coherent lavas and hyaloclastites in Southwest Hokkaido, Japan. Sed. Geol., 74, 5-23.

Yamamoto, T. (1991) Late Cenozoic dike swarms and tectonic stress field in Japan. Bull. Geol. Surv. Japan, 42, 131-148 (in Japanese with English abstract).
Yoshida, T., Ohguchi, T., Hayashi, S., Itaya, T. and Yamazaki, T. (2004) Occurrence, K-Ar ages and petrology of the Tateyamazaki basalt, Daijima Formation, Oga Peninsula, northeast Japan. Abstract, 2004 Meeting of Japan. Assoc. Mineral. Petrol. Economic Geol., 227-227 (in Japanese).

Received April, 28, 2008

Accepted July, 31, 2008 


\section{大陸縁辺の後期始新世火山活動：東北日本男鹿半島, かぶき岩の火山岩相 \\ 大口健志・山岸宏光・小林紀彦・鹿野和彦 \\ 要 旨}

男鹿半島西部北西海岸のかぶき岩は, 後期始新世の玄武岩質安山岩アア溶岩・枕状溶岩, デイサイト火碎流堆積物と ラハール堆積物などの火山岩再堆積物からなる. 陸上火山噴出物と水底火山噴出物との共存は, 当時のかぶき岩が水際 にあったことを示す．かぶき岩から連続するこれらの岩石は，周辺地域に打いて同時期の，北東南西方向に延びた平行 岩脈群と同方向の正断層群と共存しており，前期中新世に日本海が急速に拡大する前の，火山活動を伴いながらゆっく り沈降する展張場に噴出したと考えられる。 


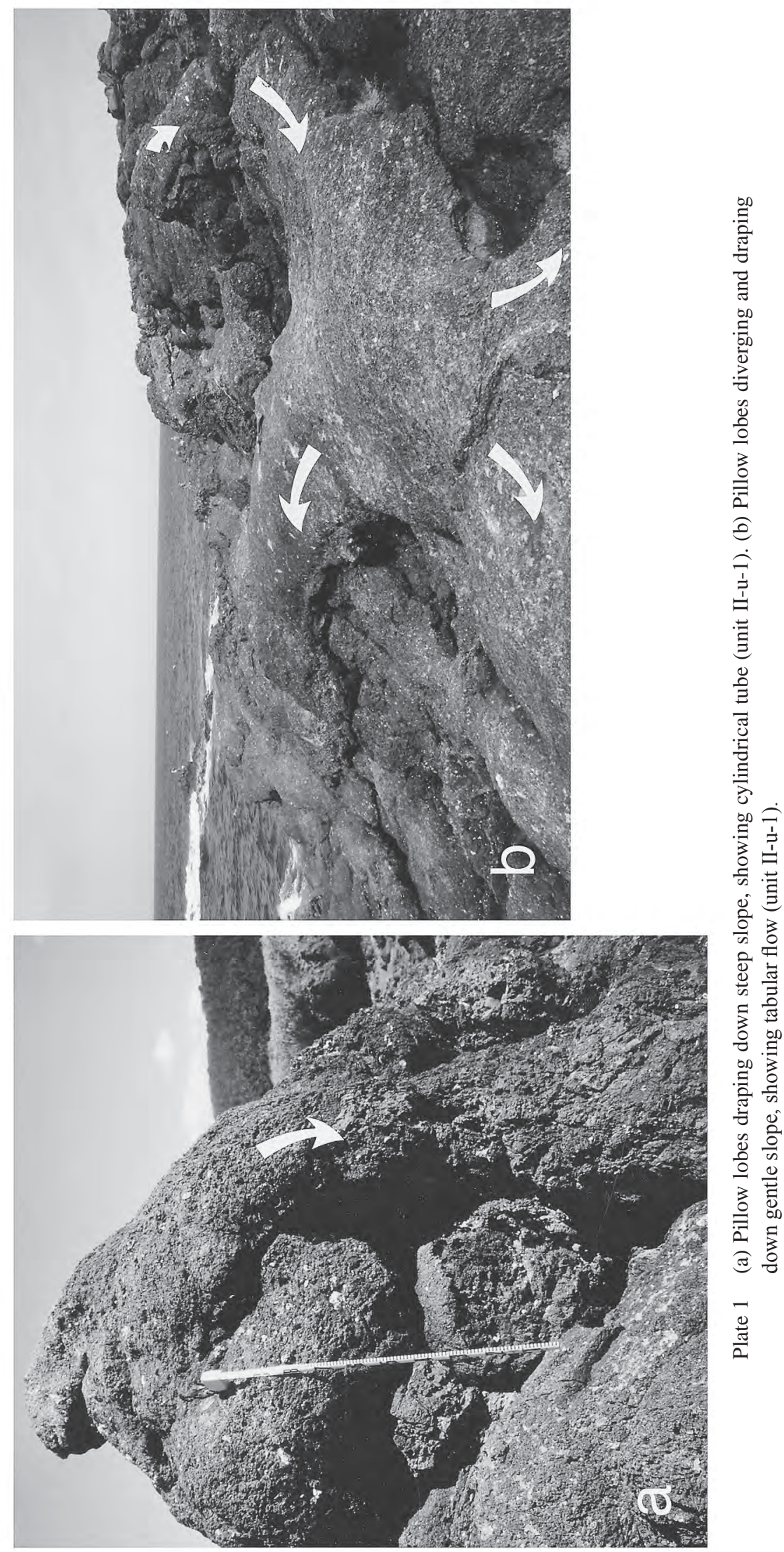



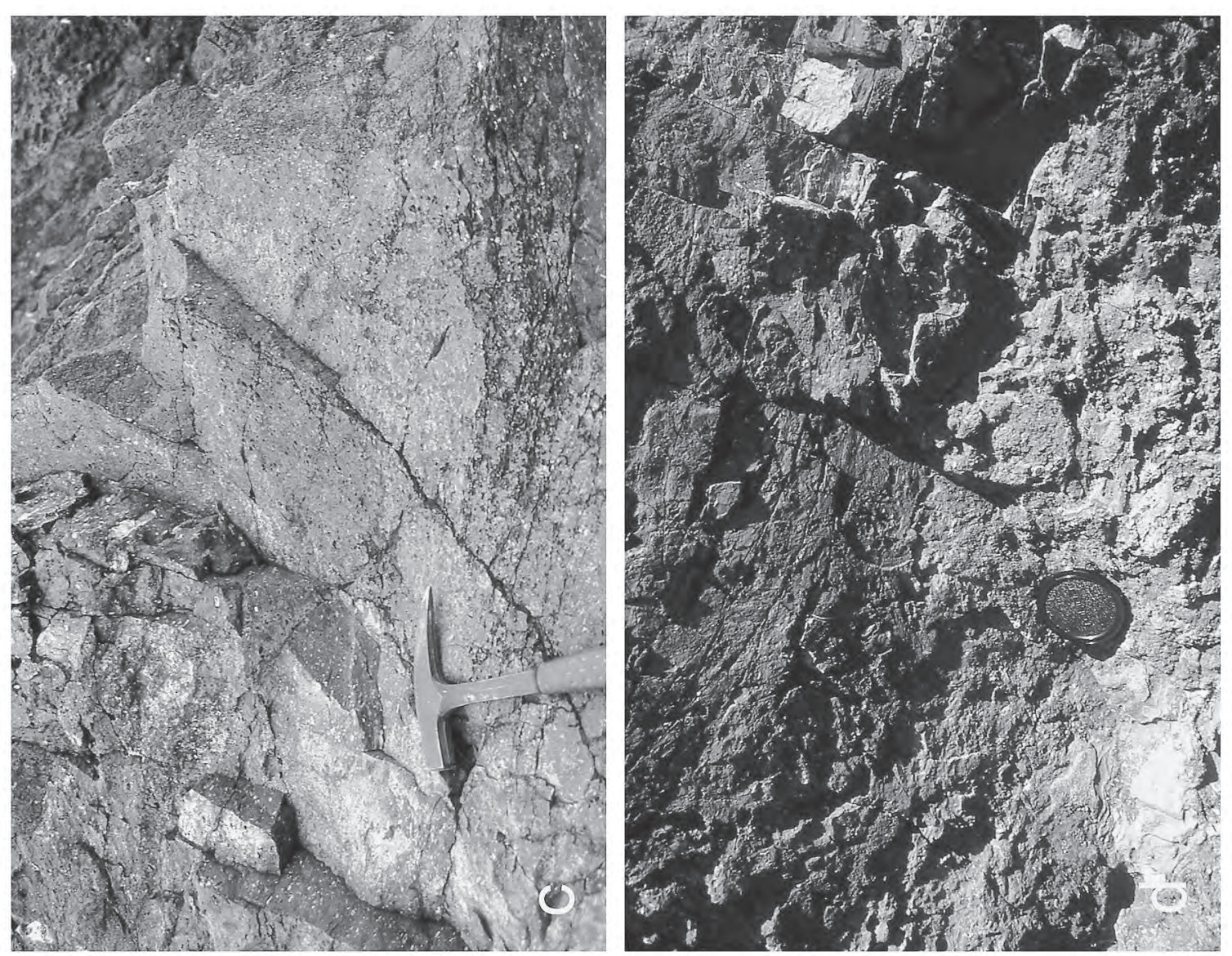

호

응

을

s.50 के

冚

on 0

릴

घี

$\frac{1}{3}$

을
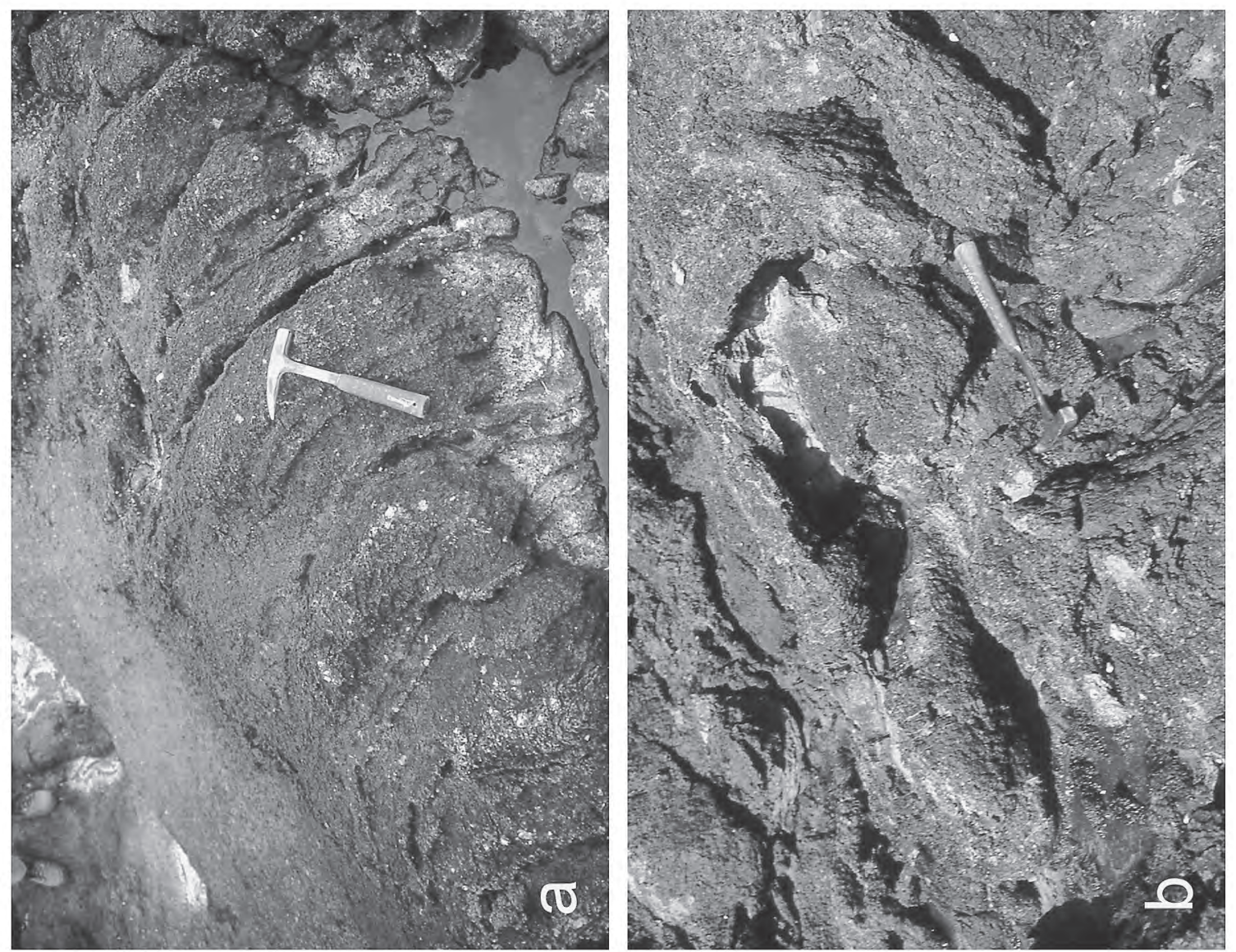

즐 全第首 $\dot{\overline{1}} \sum^{2}$ 

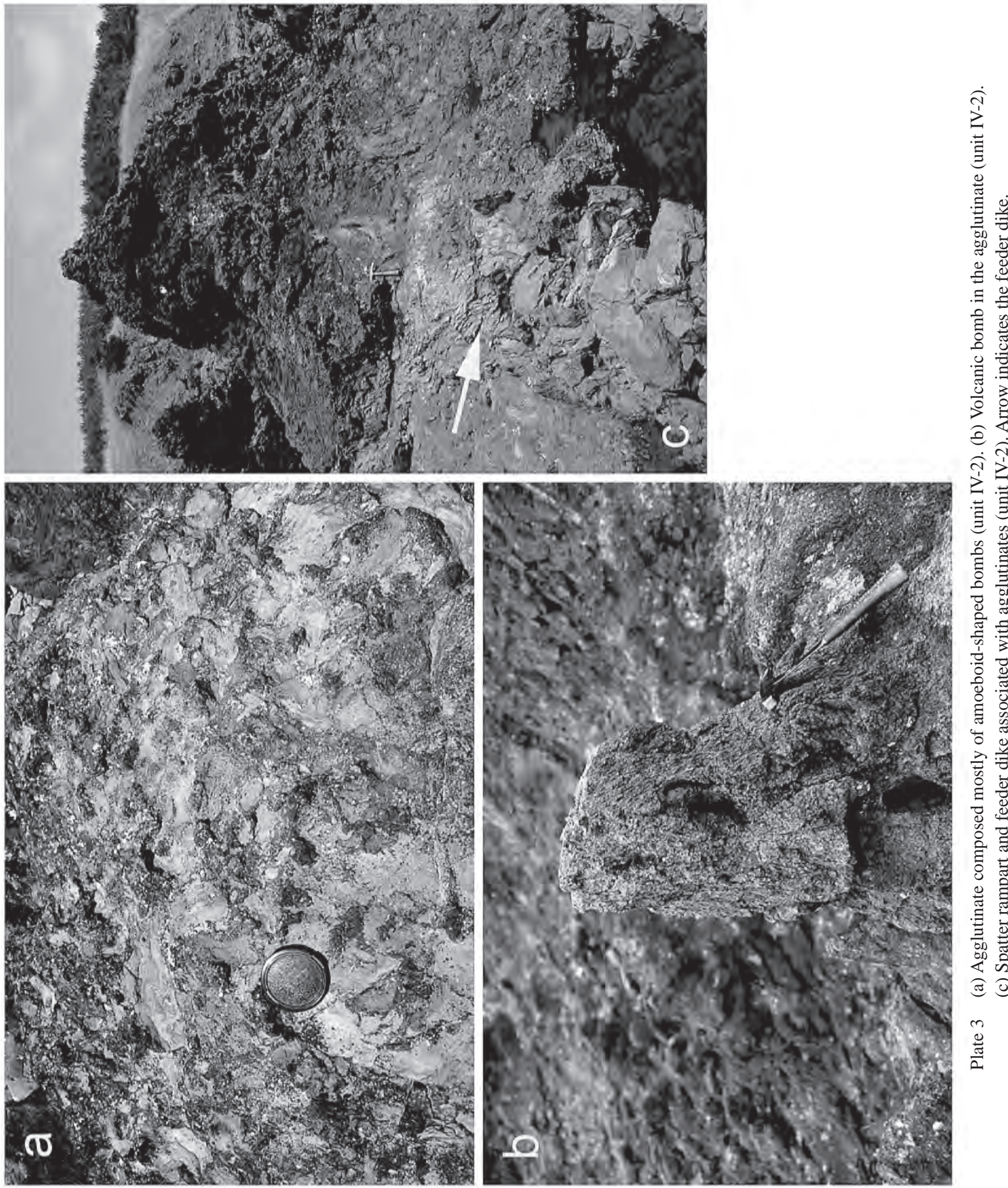